\title{
INHERITANCE STUDIES OF GREENBUG (TOXOPTERA \\ GRAMINUM ROND.) RESISTANCE IN FOUR \\ VARIETIES OF WINTER BARLEY
}

\author{
by \\ OLIN DAIL SMITH \\ Bachelor of Science \\ Oklahoma Agricultural and Mechanical College \\ Stillwater, Oklahoma \\ 1954
}

Submitted to the Faculty of the Graduate School of the Oklahoma State University

in partial fulfillment of the requirements

for the degree of

MASTER OF SCIENCE

May, 1961 


\title{
INHERITANCE STUDIES OF GREENBUG (TOXOPTERA
}

\author{
GRAMINUM ROND.) RESISTANCE IN FOUR
}

VARIETIES OF WINTER BARLEY

Thesis Approved:
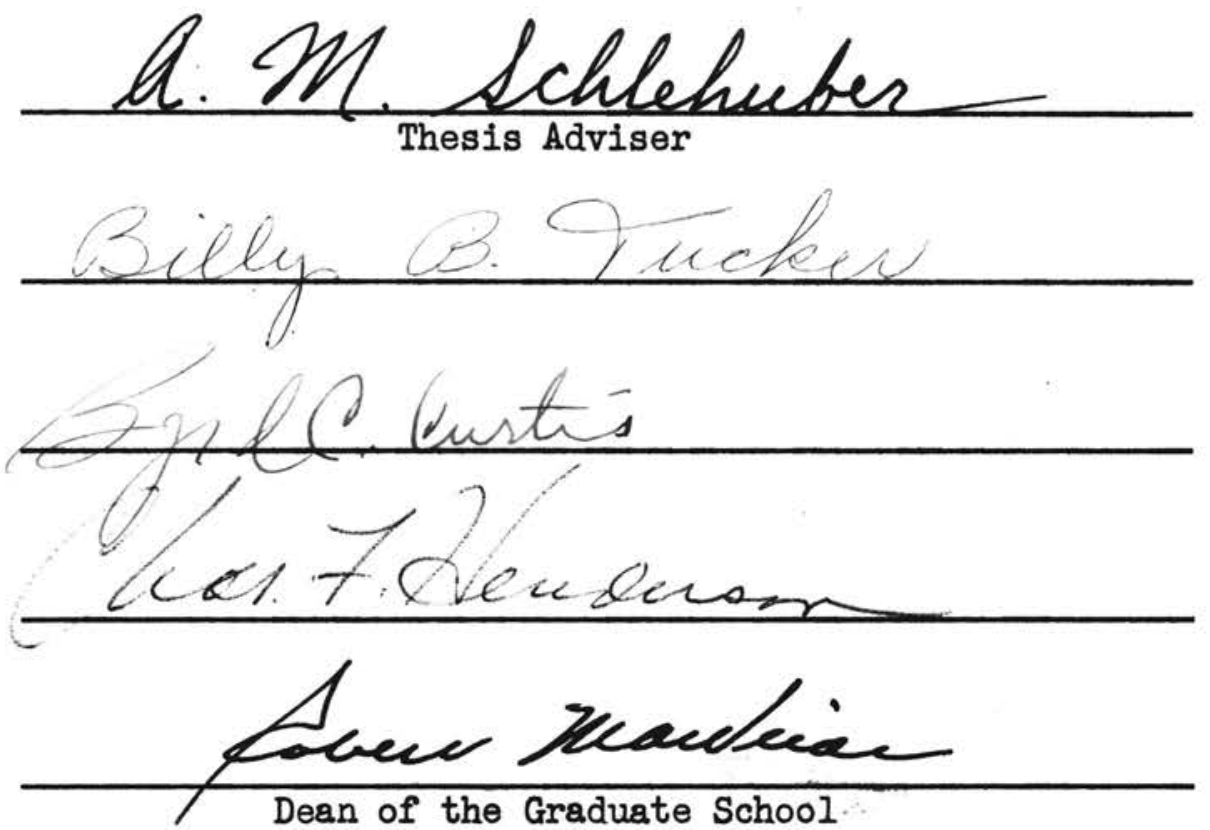


\section{ACKNOWLEDGEMENTS}

It is with sincere appreciation that I wish to acknowledge the competent instruction and counsel of my major adviser, Dr. A. M. Schlehuber. I am most grateful to $\mathrm{Dr}$. Byrd C. Curtis for his many useful suggestions in conducting the study and helpful criticisms in the preparation of the manuscript. Appreciation is extended to Dr. Billy B. Tucker and Mr. C. F. Henderson for their suggestions and constructive criticism of the manuscript.

Special thanks are due to Mr. E. A. Wood, Jr. of the Department of Entomology for his helpful advice and assistance during the course of this study.

The assistance received from members of the Small Grain Section of the Department of Agronomy in planting, harvesting and threshing the materials used is deeply appreciated. To Oklahoma State University, I am especially indebted for providing time and facilities for this investigation.

Deepest appreciation is extended to my wife, Thelma, and children, Brenda and Brent, for their affection and patience during the course of this study.

\section{9}


TABLE OF CONTENTS

Page

INTRODUCTION . . . . . . . . . . . . . . . . I 1

REVIEW OF LITERATURE . . . . . . . . . . . . . 3

Origin and Biology of the Greenbug. ........... 3

Economic Loss and Methods of Control. . . . . . . . 5

Inheritance Studies . . . . . . . . . . . 7

MATERIALS AND METHODS. . . . . . . . . . . . 10

EXPERIMENTAL RESULTS . . . . . . . . . . . . 16

General Observations. .............. 16

Resistant x Resistant Variety Studies . . . . . . . 16

Resistant x Susceptible Variety Studies . . . . . . . 18

Omugi x Tenkow. . . . . . . . . . . . . 18

Omugi $\mathrm{x}$ Ward. ................. 18

Dobaku $\mathrm{x}$ Tenkow ................. $2 I$

Dobaku $\mathrm{x}$ Ward ................ 21

DISCUSSION AND CONCLUSIONS . . . . . . . . . 25

Testing Conditions. . . . . . . . . . 25

Resistant x Resistant Variety Studies . . . . . . . 25

Resistant x Susceptible Variety Studies . . . . . . . 26

Genetic studies with Tenkow as the common parent. . . . . 26

Genetic studies with Ward as the common parent. . . . . 27

Comparisons of the susceptible parents and their progeny. . 28

SUMMARY. . . . . . . . . . . . . . . 30

LITERATURE CITED . . . . . . . . . . . . . . . 31 


\section{LIST OF TABLES}

\section{Table}

1. Greenbug reaction of parents, checks and $F_{1}$ and $F_{2}$ hybrids of resistant $x$ resistant varieties. . . . . 17

2. Greenbug reaction of parents and $F_{1}$, testcross and $\mathrm{F}_{2}$ hybrids of Omugi and Tenkow. . . . . . . . 19

3. Greenbug reaction of parents and $F_{1}$, testcross and $\mathrm{F}_{2}$ hybrids of Omugi and Ward. . . . . . . . . 20

4. Greenbug reaction of parents and $F_{1}$, testcross and $\mathrm{F}_{2}$ hybrids of Dobaku and Tenkow . . . . . . . . 22

5. Greenbug reaction of parents and $F_{1}$, testcross and $\mathrm{F}_{2}$ hybrids of Dobaku and Ward. 


\section{INTRODUCTION}

Considerable time, money and effort has been put forth during the past 15 years in attempts to breed greenbug (Toxoptera graminum Rond.) resistant barley varieties with good agronomic characteristics. Much of this work has been done in the absence of definite knowledge of the mode of inheritance of greenbug resistance. The results have often been disappointing, not from failure to incorporate greenbug resistance in hybrids but in maintaining good agronomic characters, particularly good straw strength, when greenbug resistance was acquired. In the event that some linkage may exist in some varieties between genes conditioning weak straw and greenbug resistance, it seemed desirable to determine if there are different genetic factors controlling resistance. If so, it may be easier to obtain the desired genetic combination from 1 resistant varietal source than another. Only a few resistant barley varieties could be included in this study because of limitations on time and facilities. Therefore, 4 resistant varieties of diverse origin which have been previously tested at the Oklahoma station were selected.

It was also deemed advisable to investigate further the inheritance of greenbug resistance. McDonald (22) $1 /$ obtained some information on this subject in his Master's study conducted at this station in 19501951 but his results were not conclusive.

1/ Figures in parentheses refer to "Literature Cited", page 31. 
The objectives of this study were as follows:

(I) to determine if the greenbug resistance of Omugi, Dobaku, Kearney and the unnamed variety C.I. $2 / 5087$ is due to the same or different genes.

(2) to determine the genetics of the greenbug resistance of Omugi and Dobaku by crossing them with the susceptible varieties, Tenkow and Ward.

2/ Accession number assigned by the Division of Cereal Crops and Diseases, U. S. Department of Agriculture. 
REVIEW OF LITERATURE

Origin and Biology of the Greenbug

The first exact knowledge of the insect commonly known as the greenbug (Toxoptera graminum, Rond.) came from Parma, Italy in 1847 (33). Washburn (32) states it was first described in 1852 by Dr. C. Rondani under the name of Aphis graminum and was redescribed in 1863 by Passerini and placed in the genus Toxoptera. Kelly (20) and Wadley (29) distinguish the greenbug from the other species of aphids by the pea green color with the darker green dorsal line, black eyes and green cornicles with dark tips. They and Fenton (15) state the winged form has a singly branched discoidal vein in the front wing as compared to the twice branched vein in other similar appearing species. Wadley reports the aphids are approximately $1.8 \mathrm{~mm}$. in length and 0.8 to $0.9 \mathrm{~mm}$. in width. Webster and Phillips (33) state the general color of the larvae and pupae is similar to that of the apterous females.

Three distinct forms of adult females are listed by Walton (31) as follows: wingless viviparous, winged viviparous and wingless oviparous. The viviparous forms reproduce asexually and the oviparous forms sexually. Dahms (8) and Walton (31) report that in southern latitudes, except at high altitudes, all wingless forms are female and are viviparous. Kelly (20) states greenbugs reproduce asexually south of the 35 th parallel and both sexually and asexually north of this parallel. However, Daniels (11) and Daniels et al. (13) state males have been observed 
under Texas conditions and eggs have been found in the greenhouse. They report none of the eggs have hatched and that eggs have not been found under field conditions in that area. Daniels (1l) suggests that at higher altitudes in the southern states the egg may be one of the oversummering stages.

Most females begin reproduction in 6 to 30 days after birth (8, 13, $19,28,29,31,33)$. Some differences in rates of reproduction are reported by these authors; however, it may be concluded that each female will produce 40 to 60 young at the rate of 2 to 4 per day. These authors agree that temperature has a pronounced influence on the age when reproduction begins and the rate of reproduction thereafter. According to Daniels et al. (13) reproduction is most rapid at $55^{\circ}$ to $80^{\circ} \mathrm{F}$. but some reproduction occurs at temperatures as low as $40^{\circ}$. They also state that greenbugs may survive temperatures near $0^{\circ}$ to $105^{\circ} \mathrm{F}$. This, in general, is in agreement with the previously mentioned authors.

In addition to the greenbug feeding on the plant, it is probable that in some way the pest poisons the plant tissues (31). Chatters and Schlehuber (4) made an intensive investigation into the mechanics of feeding and subsequent damage caused by the greenbug when feeding on small grains. They found the stylet enters intercellularly and appears to be directed towards the phloem, the ultimate site of feeding. They stated the injection of saliva, not the uptake of food, appears to be the primary cause of tissue damage. They theorized potent enzymes in the saliva caused the lysis in Hordeum, cell wall modification in Avena and a combination of lysis and cell wall modification in Triticum. The implications from these studies were that resistance to the greenbug is physiological. 
Little is known of greenbug biotypes under field conditions. Curtis et al. (6) and Wood (36) have reported the appearance of a new biotype in greenhouse culture. This new strain destroyed plants of 2 varieties of wheat which previously had been resistant. Little or no difference was found in the response of barley between the greenhouse and field cultures. Dahms (7) studied the tolerance of 15 varieties of wheat, oats and barley to greenbugs collected from Mississippi and Oklahoma. He found no significant difference in the aphids from the 2 sources as measured by the response of the plants.

\section{Economic Loss and Methods of Control}

Fifteen serious greenbug outbreaks have occurred in the United States since 1882, each causing losses estimated at more than 50 million bushels of grain (10). Dahms (8) states that all serious outbreaks have occurred when the previous summer was cool and moist, followed by a mild winter and a cool, late spring.

According to Fenton (15), damage to fields of small grains by the greenbug during the late fall, winter, and early spring consists of a series of more or less well defined spots in the field where the plants have been killed or severely injured. In the spring, if conditions are favorable, the spots rapidly enlarge until the entire field is infested. Painter et al. (25) state late fall and early spring feeding by greenbugs thins and prevents tillering of the plants and later, feeding behind the leaf sheath causes stunting of the heads. Painter (24) reports greenbugs may move in and feed behind the boot after the plants have headed, reducing the number and plumpness of the grain.

Good cultural practices, burning or plowing of early infested spots 
and destruction of volunteer were recommended as control measures by early research workers -- Hunter (19), Webster and Phillips (33) and Bilsing (2). Good cultural practices increases plant vigor and causes a marked effect on the extent of damage $(8,16)$. The destruction of the volunteer was to prevent oversummering of the greenbug. However, Patch (27), Dahms et al. (9) and Daniels (12) have found many other gramineous plants to serve as food plants for this aphid. The latter author found the greenbugs to oversummer in the Texas Panhandle on western wheatgrass, Agropyron smithii (Rydb.).

The greenbug is attacked by species of the genera Hippodamia, Nabis, Syrphidae, Chrysopa and Aphidius, according to Daniels et al. (13). Hunter (19) recommended the artificial dispersion of Lysiphlebus sp. as a greenbug control measure. Wood (35) reported a species of Aphelinus parasitizing greenbugs in Oklahoma in 1956.

Webster and Phillips (33) were perhaps the first to suggest chemical control of the greenbug. Dahms (8) tested several materials and found parathion spray to be the most effective. A number of insecticides are now available for greenbug control (13).

The first observation of small grain varietal differences to greenbug attack was recorded by Wadley (29) in 1931. He found it difficult to increase the aphids on Mindum durum and Vernal emmer wheat. Fenton and Fisher (16) found winter barley to be a preferred host to winter wheat. Varietal differences in reaction to greenbugs was observed in small grains by Atkins and Dahms (1) in 1942. They reported a high type of resistance among some barley varieties, moderate resistance in some wheat varieties and a lower degree of resistance in oats. Among the barley varieties observed to be resistant were Omugi, Dobaku and an 
unnamed variety designated C.I. 5087. They state the majority of the barley strains showing high resistance to greenbugs originated in the Orient. Dahms et al. (10) and Chada et al. (3) also have found most of the resistant barley varieties to be of oriental origin. The latter authors tested 4445 spring type and 1230 winter type barley varieties from the world collection. Of the 77 most resistant winter barley varieties, 69 were from foreign countries of which 43 came from the Orient. The association of plant characters and greenbug resistance was studied by Grant (18). No significant correlation was found although the varieties with the best resistance had long rachilla and rachis hairs, and the varieties showing the least resistance had short rachilla hairs. Maxwell and Painter (21) found an inverse relation between the rate of honeydew deposition by greenbugs and the amount of resistance in the host plants.

\section{Inheritance Studies}

Resistant segregates in progeny of barley crosses involving resistant varieties were first observed by Atkins and Dahms (1). MeDonald (22) studied the genetics of greenbug resistance in crosses involving 2 resistant varieties, Omugi and Dobaku, and a semi-resistant variety, C.I. 5087. $F_{2}$ and limited numbers of $F_{1}$ plants were analyzed for resistance on the basis of leaf injury and retardation of plant growth. He concluded 3 gene pairs controlled resistance of which 2 were dominant and 1 was recessive. Genotypes were assigned as follows: Dobaku, Grb ${ }_{1}^{-}$ $\mathrm{Grb}_{1} \mathrm{grb}_{2} \mathrm{grb}_{2}$; Omugi, $\mathrm{Grb}_{1} \mathrm{Grb}_{1} \mathrm{Grb}_{3} \mathrm{Grb}_{3}$; C.I. 5087, $\mathrm{grb}_{1} \mathrm{grb}_{1} \mathrm{grb}_{2} \mathrm{grb}_{2}$; Tenkow, $\mathrm{grb}_{1} \mathrm{grb}_{1} \mathrm{grb}_{3} \mathrm{grb}_{3}$; and Ward, $\operatorname{grb}_{1} \mathrm{grb}_{1} \mathrm{Grb}_{2} \mathrm{Grb}_{2}$. The genes controlling resistance were designated $\mathrm{Grb}_{1}, \mathrm{grb}_{2}$ and $\mathrm{Grb}_{3}$. Although he 
assigned the genotype $\mathrm{Grb}_{1}$ to both Omugi and Dobaku, he was not able to determine if the varieties carried a common gene for resistance.

The inheritance of resistance in Omugi in crosses with 6 susceptible varieties -- Cordova, Mo B538, Caucasus, Khayyam, Hokudo and a selection from the cross Cordova $x$ Goliad (Texas Sel. 47-53-1249) -- was studied by Gardenhire and Chada (17). $F_{1}, F_{2}$ and $F_{3}$ data based on leaf injury, longevity and degree of stunting showed the greenbug resistance of Omugi to be conditioned by a single dominant gene. No reciprocal crosses were made but reference is made by these authors to a preliminary study of reciprocal crosses of Omugi and Cordova in which no cytoplasmic inheritance was found. These authors also refer to data obtained from testing $F_{4}$ and $F_{5}$ selections of Cordova $x$ Omugi bulk hybrids which indicated that resistance in Omugi was monogenic.

Unpublished data from $F_{2}$ barley greenbug tests conducted at the Oklahoma Agriculture Experiment Station in 1959 also gave indication that Omugi has 1 dominant gene pair controlling resistance. The susceptible varieties used in these tests were Rogers and Composite Hybrid Selection C.I. 9526. Rogers $x$ Omugi and Ward x Omugi-Ward lines were used as the resistant parents.

In other phases of the study conducted by Gardenhire and Chada (17), Omugi was crossed with the resistant varieties Kearney and Derbent. On the basis of $\mathrm{F}_{2}$ and $\mathrm{F}_{3}$ data they concluded that the same gene or closely linked genes controlled the resistance of these varieties. Association studies of greenbug resistance with plant characters controlled by single marker genes on chromosomes 1, 2, 4, 5 and 7, revealed the gene conditioning resistance was either not on the chromosomes tested or were more than 50 crossover units from the marker gene. 
Greenbug resistance in the wheat selection Dickinson $28 \mathrm{~A}$ is controlled by a single recessive gene, according to Painter and Peters (26), Daniels and Porter (14) and Curtis, Schlehuber and Wood (6). Daniels and Porter suggested modifying genes may be present as the $F_{1}$ had slightly more tolerance than the susceptible parent. Curtis et al. found susceptibility was incompletely dominant and that the resistance of Dickinson Selection 28A and C.I. 9058 are controlled by a common gene. They were unable to locate the chromosome involved by monosomic genetic studies. 
MATERIAIS AND METHODS

The greenbug resistant winter barley varieties used in this study were Omugi C.I. 5144, Dobaku C.I. 5238, Kearney C.I. 7580 and an unnamed variety C.I. 5087. The susceptible varieties were Tenkow C.I. 646 and Ward C.I. 6007. Omug1, Dobaku, C.I. 5087, Tenkow and Ward were chosen as this investigation is a continuation of the study conducted by McDonald (22). Kearney was included because much use has been made of this variety as a source of greenbug resistance in the barley breeding program at the Oklahoma Agricultural Experiment Station.

Omugi is a 6-rowed variety which was introduced from Korea (10). It has erect early growth, long and wide leaves, and fair winterhardiness. The spikes are middense, midlong, nodding and rough-awned. Omugi is midseason, midtall and produces fair jields. It has relatively weak straw.

Dobaku is a 6-rowed variety which was introduced from Korea (10). It has erect early growth, long and wide leaves, and fair winterhardiness. The spikes are dense, short to midlong, nodding and rough-awned. It is midseason, midtall and produces fair yields. The straw is relatively weak.

C.I. 5087 is a 6-rowed variety which was introduced from China (10). The leaves are narrow, midlong and drooping; early growth is prostrate. The degree of winterhardiness is not known. The spikes are lax, midlong, nodding and the awns are modified into elevated hoods. C.I. 5087 is early in maturity but appears to be low in yielding ability. It also 
has relatively weak straw.

Kearney, distributed by the Nebraska station in 1952, is a selection from Composite Cross III C.I. 5530 (34). It is one of the most winterhardy varieties known. It is 6-rowed, rough-awned, midseason and midtall. Early growth is semiprostrate to prostrate; leaves are long, narrow and drooping. The spikes are lax to dense, short to midlong and nodding. The straw is relatively weak.

Tenkow came from the cross Tennessee Winter $x$ Hankow (34). The exact year of selection is not known but it was in yield nurseries in Virginia as early as 1911. It was released by the Oklahoma station in 1941. Tenkow is a 6-rowed, rough-awned winter barley with moderate winterhardiness. Early growth is semiprostrate and leaves are long, wide and drooping. It is midseason and midtall. The spikes are lax, midlong and nodding. Tenkow produces good yields but has moderately weak straw and is susceptible to most of the common barley diseases. It was dropped from the Oklahoma list of recommended varieties in 1959. Ward is a local barley that had been grown for many years in northwestern Oklahoma before it was obtained by the United States Department of Agriculture in 1931 (34). It was named and released at the U. S. Southern Great Plains Field Station at Woodward, Oklahoma in 1936. Ward is a 6-rowed, rough-awned winter variety with good winterhardiness. Early growth is semiprostrate to prostrate and leaves are long, narrow and drooping. The spikes are lax, midlong and nodding. It produces good yields but has moderately weak straw and is susceptible to most of the common barley diseases. It was removed from the list of recommended varieties in Oklahoma in 1961.

The greenbug cultures used were obtained from the field, increased 
and distributed on the material tested by Mr. E. A. Wood, Jr., Entomologist, USDA, Stillwater, Oklahoma.

The greenbug reaction tests were conducted in the greenhouse insectary in a manner similar to that described by Curtis (5). A brief description of these techniques follows:

The tests were seeded in galvanized iron flats having inside measurements of approximately $13 \times 20 \times 3 \frac{1}{2}$ inches. The bottom of the flats were constructed of corrugated iron with 5/16 inch holes evenly distributed along the lower portion of the corrugations. These holes were to facilitate subirrigation by placing the flats in trays of water.

The flats were filled with a soil mixture consisting of 4 parts Norge loam soil, 1 part peat moss, 1 part sterilized manure and 1 part washed river sand. Twenty-four grams of dry commerical fertilizer consisting of approximately 3.2 grams available $\mathrm{N}, 4.0$ grams $\mathrm{P}_{2} \mathrm{O}_{5}$ and 2.4 grams $\mathrm{K}_{2} \mathrm{O}$ was blended with the soil mixture in each flat. The contents of each flat were divided into 10 rows, 13 inches long, 2 inches apart and $\frac{1}{2}$ inch deep with a corrugated row marker which fitted the inside of the flats. With few exceptions, where seed supply was limited, 15 seeds were evenly spaced in each row. The flats were then filled to the top with sand and watered. Automatic room temperature controls were set for $70^{\circ} \mathrm{F}$. and temperatures were maintained between 65 and 80 degrees. Greenbugs which had been increased on cultures of Ward barley were distributed as uniformly as possible on the plants soon after emergence. The aphid populations were checked closely for the succeeding few days and additional greenbugs were added to flats having low infestations.

All crosses were made in the greenhouse during the winter months of 1958-1959 and 1959-1960. It was hoped that sufficient $F_{0}$ seed could be 
obtained during the 1958-1959 season for subsequent testing and increase. However, additional crossing was necessary to provide adequate populations for $F_{1}$ tests.

In the resistant $x$ resistant variety studies, Omugi, Dobaku, Kearney and C.I. 5087 were crossed in all combinations including reciprocals. One to $6 F_{1}$ and reciprocal $F_{1}$ plants were grown with parent plants during the 1959-1960 season to determine if the crosses were effected and for increase of $F_{1}$ seed. All crosses and reciprocals were obtained. $F_{1}$ 's, $F_{2}$ 's, parents and checks were subjected to greenbug attack in 1960-1961. A susceptible check, Ward, was seeded in the fifth row of each flat. Parents and hybrid progenies were seeded in the same flats.

In the resistant $x$ susceptible studies, crosses and reciprocal crosses of both Omugi and Dobaku were made with Tenkow and Ward. Two to $6 F_{1}$ and reciprocal $F_{1}$ plants were grown with parents in the 1959-1960 season for making testcrosses and for production of $F_{1}$ seed. Six or more additional $F_{1}$ and reciprocal $F_{1}$ plants, with parents, were subjected to a preliminary test for greenbug reaction to determine whether the resistant or susceptible parents should be used for testcrosses. Since this test indicated that at least $I$ dominant resistant gene was involved, backcrosses were made to the susceptible parents. $F_{1}, F_{2}$ and testcross hybrid plants with parents were tested in 1960-1961 for their response to greenbug infestation. The parents and hybrid progenies were seeded in the same flats.

The greenbug reaction tests were seeded on December 5, 1960. The flats were placed in metal trays 2 inches deep and large enough to contain 4 or 10 flats. The trays were filled to within $\frac{1}{2}$ inch of the top with water and left overnight. Excess water was drained from the trays 
the following morning.

Difficulty was encountered at the beginning of the test in that the time of emergence was very erratic. Bmergence began on December 9 but was not complete until December 19. This irregularity in emergence was thought to be caused by a shortage of available oxygen in the soil; the oxygen supply being limited by saturated soil. The evidence for this hypothesis was that emergence was slowest in those flats or parts of flats which were located in portions of trays where the water was deepest. The flats were removed from the trays on December 12 and placed on tables in hopes of reducing the moisture content of the soil. The flats were left on these tables for the remainder of the test.

Another difficulty encountered at the beginning of the test was that the greenbug cultures did not increase as rapidly as expected. Consequently, only light infestations (approximately 800 greenbugs per flat) were applied on December 12. The populations were increased to 1500 to 2000 bugs per flat on December 19. After this, the flats were carefully watched and additional bugs were added where populations did not appear adequate.

Stunting of susceptible checks was first apparent 8 to 10 days after the initial infestation. Each plant was observed at 2-day intervals and the date was recorded when the plant appeared dead or was believed to be beyond the point of recovery. This point beyond recovery may be described as the stage when the entire seedling appears to be dead except for a slight yellowish green area near the soil surface. On December 27 the first plants reached such a stage of injury.

The resistant parents, checks and hybrids grew very rapidly reaching heights of 12 to 14 inches by December 29. Much lodging resulted 
from this excessive growth so the plants were clipped on this date to a maximum height of $3 \frac{1}{2}$ inches. This was accomplished by laying a board of this width on edge between the rows as a guage, and cutting the plants off even with the upper edge of the board. The detached leaves were distributed in the flats and were removed after the aphids had migrated to the plants. By January 24 the resistant plants were again becoming quite tall and beginning to lodge. Since all plants which offered any indication of susceptibility in the resistant $\mathrm{x}$ resistant variety studies were dead or beyond the point of recovery, final counts of both resistant and susceptible plants were made and this portion of the test discontinued. Complete counts were also made on the resistant $\mathrm{x}$ susceptible hybrids and parents. However, to be more certain that occasional susceptible plants had not escaped, these were trimmed to a maximum height of $5 \frac{1}{2}$ inches in the manner described earlier and additional greenbugs were applied. On February 4 final counts of resistant and susceptible plants were made and the test discontinued. Of the plants still living at this date, only occasional plants which showed definite severe greenbug injury were classified as susceptible. The remaining were assumed to be resistant. 


\section{EXPERIMENTAL RESULTS}

\section{General Observations}

Erratic emergence followed by excessive growth of the plants caused considerable variation in the time of death of the individual plants even among susceptible checks; hence, duration of life was of little aid in detecting minor differences in degrees of resistance. However, the difference in tolerance between resistant and susceptible parents and checks was easily observed. The average date of death of the 1089 susceptible parents and checks was January 11, assuming the 29 plants which lingered at the close of the test would have died an average of 5 days later.

Clipping the plants to a maximum height of $3 \frac{1}{2}$ inches at 10 to 17 days of age or to $5 \frac{1}{2}$ inches at 36 to 44 days of age apparently did not affect their greenbug resistance. The resistant parents and hybrids recovered very rapidly as compared to the susceptible parents and checks.

No evidence of cytoplasmic inheritance was observed in any of the crosses. Similar ratios were obtained with reciprocal crosses.

\section{Resistant x Resistant Variety Studies}

A total of $228 \mathrm{~F}_{1}$ and $2132 \mathrm{~F}_{2}$ hybrids from 6 crosses and reciprocal crosses among 4 greenbug resistant varieties were tested for their reaction to greenbugs. The number of parent, check, $F_{1}$ and $F_{2}$ plants are presented in table 1. No segregation was observed; all $F_{1}$ and all but 1 
Table 1.--Greenbug reaction of parents, checks and $F_{1}$ and $F_{2}$ hybrids of resistant $x$ resistant varieties.

\begin{tabular}{lccc}
\hline & \multicolumn{3}{c}{ Number of plants } \\
\cline { 2 - 4 } Variety or cross & Res. & Susc. & Total \\
\cline { 2 - 4 } & & & \\
Parents and checks & 329 & 1 & 330 \\
Omugi & 358 & 0 & 358 \\
Dobaku & 266 & 1 & 267 \\
Kearney & 285 & 0 & 285 \\
C.I. 5087 & 0 & 400 & 400 \\
Ward & & & \\
& & & \\
F hybids I/ & 30 & 0 & 30 \\
Omugi x Dobaku & 33 & 0 & 33 \\
Omugi x Kearney & 48 & 0 & 48 \\
Omugi x C.I. 5087 & 37 & 0 & 37 \\
Dobaku x Kearney & 51 & 0 & 51 \\
Dobaku x C.I. 5087 & 29 & 0 & 29 \\
Kearney x C.I. 5087 & & & \\
& & & \\
F hybids 2/ & 399 & 0 & 399 \\
Omugi x Dobaku & 403 & 0 & 403 \\
Omugi x Kearney & 371 & 0 & 371 \\
Omugi x C.I. 5087 & 404 & 0 & 404 \\
Dobaku x Kearney & 392 & 1 & 393 \\
Dobaku x C.I. 5087 & 162 & 0 & 162 \\
Kearney x C.I. 5087 & & & \\
& & & \\
\hline
\end{tabular}

1/ Each cross includes reciprocals.

2/ Each cross includes progenies from $2 F_{1}$ and 2 reciprocal $F_{1}$ plants except for Kearney x C.I. 5087 which includes $1 F_{1}$ and 3 reciprocal $\mathrm{F}_{1}$ plants. 
$F_{2}$ (Dobaku x C.I. 5087) plants were resistant. It is not surprising that $1 \mathrm{~F}_{2}$ plant died and was classified susceptible since 1 plant each of Omugi and Kearney succumbed and also were recorded susceptible. Possibly this can be attributed to disease organisms or seed mixtures. No differences in the degree of resistance were apparent in the $F_{1}$ 's, $\mathrm{F}_{2}$ 's or parents.

\section{Resistant $\mathrm{x}$ Susceptible Variety Studies}

\section{Omugi $\times$ Tenkow}

The data obtained on parents and hybrids with chi-square probability values for hybrid ratios of $1: 1$ for the testcrosses, and $3: 1$ and 13:3 for the $F_{2}^{\prime s}$ are shown in table 2. All $7 \mathrm{~F}_{1}$ plants were resistant. The number of resistant and susceptible progenies of 2 testcrosses approximated a $1: 1$ ratio. Three of the $4 \mathrm{~F}_{2}$ populations tested segregated 3 resistant to 1 susceptible with probability values between .50 and .90 . There were too many susceptible plants in the fourth population for a $3: 1$ ratio. A total of $373 \mathrm{~F}_{2}$ plants were tested of which 273 were resistant and 100 were susceptible. Probability values for pooled chi-square based on a $3: 1$ ratio are $.40-.50$ and less than .005 for a 13:3. The deviation from the expected $3: 1$ ratio was in the direction of too many susceptible plants. This resulted primarily from the population designated 60 G 971-4 which did not fit the hypothesized ratio. $\underline{\text { Omugi } \times \text { Ward }}$

The number of parent and $F_{1}$, testcross and $F_{2}$ hybrids from crosses of these varieties are shown in table 3 . Twenty-five of the $28 \mathrm{~F}_{1}$ plants tested were resistant. The cause of $3 \mathrm{~F}_{1}$ 's being susceptible is not known but perhaps it can be attributed to weak plants originating from 
Table 2.--Greenbug reaction of parents and $F_{1}$, testcross and $F_{2}$ hybrids of Omugi and Tenkow.

\begin{tabular}{|c|c|c|c|c|c|c|}
\hline \multirow[t]{2}{*}{ Variety or cross } & \multicolumn{3}{|c|}{ Number of plants } & \multicolumn{3}{|c|}{$P$ values for res.: susc ratios of: } \\
\hline & Res. & Susc. & Total & $1: 1$ & $3: 1$ & $13: 3$ \\
\hline $\begin{array}{l}\text { Parents } \\
\text { Omugi } \\
\text { Tenkow }\end{array}$ & $\begin{array}{r}80 \\
0\end{array}$ & $\begin{array}{r}1 \\
163\end{array}$ & $\begin{array}{r}81 \\
163\end{array}$ & & & \\
\hline $\begin{array}{l}\mathrm{F}_{1} \text { hybrids } \\
\text { Omugi } \mathrm{x} \text { Tenkow } \\
\text { Tenkow } \mathrm{x} \text { Omugi } \\
\text { Total }\end{array}$ & $\begin{array}{r}5 \\
2 \\
7\end{array}$ & $\begin{array}{r}0 \\
0 \\
0\end{array}$ & $\begin{array}{r}5 \\
2 \\
7\end{array}$ & & & \\
\hline $\begin{array}{l}\text { Testcross hybrids } \\
\text { Tenkow } x \text { (Tenkow x Omugi) } \\
\text { Tenkow x (Omugi x Tenkow) } \\
\text { Total }\end{array}$ & $\begin{array}{l}22 \\
14 \\
36\end{array}$ & $\begin{array}{r}30 \\
6 \\
36\end{array}$ & $\begin{array}{l}52 \\
20 \\
72\end{array}$ & $\begin{array}{l}.40-.50 \\
.10-.15 \\
.90-.99\end{array}$ & & \\
\hline $\begin{array}{l}\text { F2 }_{2} \text { hybrids } \\
\text { Omugi x Tenkow I/ } \\
60 \mathrm{G} 971-3 \\
60 \mathrm{G} 971-4 \\
\text { Tenkow x Omugi } \\
60 \mathrm{G} 983-5 \\
60 \mathrm{G} 983-6 \\
\text { Total }\end{array}$ & $\begin{array}{r}77 \\
42 \\
75 \\
79 \\
273\end{array}$ & $\begin{array}{r}24 \\
29 \\
21 \\
26 \\
100\end{array}$ & $\begin{array}{r}101 \\
71 \\
\\
96 \\
105 \\
373\end{array}$ & & $\begin{array}{r}.75-.90 \\
<.005 \\
.50-.60 \\
.90-.99 \\
.40-.50\end{array}$ & $\begin{array}{r}.20-.25 \\
<.005 \\
\\
.50-.60 \\
.05-.10 \\
<.005\end{array}$ \\
\hline
\end{tabular}

I/ Pot number of parental $F_{1}$ plant. 
Table 3.--Greenbug reaction of parents and $F_{1}$, testcross and $F_{2}$ hybrids of Omugi and Ward.

\begin{tabular}{|c|c|c|c|c|c|c|}
\hline \multirow[t]{2}{*}{ Variety or cross } & \multicolumn{3}{|c|}{ Number of plants } & \multicolumn{3}{|c|}{$P$ values for res.:susc, ratios of: } \\
\hline & Res. & Susc. & Total & $1: 1$ & $3: 1$ & $13: 3$ \\
\hline $\begin{array}{l}\text { Parents } \\
\text { Omugi } \\
\text { Ward }\end{array}$ & $\begin{array}{r}164 \\
0\end{array}$ & $\begin{array}{r}0 \\
206\end{array}$ & $\begin{array}{l}164 \\
206\end{array}$ & & & \\
\hline $\begin{array}{l}F_{1} \text { hybrids } \\
\text { Omugi x Ward } \\
\text { Ward x Omugi } \\
\text { Total }\end{array}$ & $\begin{array}{l}12 \\
13 \\
25\end{array}$ & $\begin{array}{l}2 \\
1 \\
3\end{array}$ & $\begin{array}{l}14 \\
14 \\
28\end{array}$ & . & & \\
\hline $\begin{array}{l}\text { Testcross hybrids } \\
\text { Ward } \mathrm{x} \text { (Ward } \mathrm{x} \text { Omugi) } \\
\text { Ward } \mathrm{x} \text { (Omugi } \mathrm{x} \text { Ward) } \\
\text { (Ward } \mathrm{x} \text { Omugi) } \mathrm{x} \text { Ward } \\
\text { (Omugi } \mathrm{x} \text { Ward) } \mathrm{x} \text { Ward } \\
\text { Total }\end{array}$ & $\begin{array}{l}61 \\
17 \\
27 \\
16 \\
121\end{array}$ & $\begin{array}{l}49 \\
10 \\
27 \\
17 \\
103\end{array}$ & $\begin{array}{r}110 \\
27 \\
54 \\
33 \\
224\end{array}$ & $\begin{array}{l}.30-.40 \\
.20-.25 \\
.90-.99 \\
.90-.99 \\
.25-.30\end{array}$ & & \\
\hline $\begin{array}{l}\mathrm{F}_{2} \text { hybrids } \\
\text { Omugi x Ward } \\
60 \mathrm{G} 974-4 \\
60 \mathrm{G} 977-2 \\
\text { Ward x Omugi } \\
60 \mathrm{G} 986-1 \\
60 \mathrm{G} 989-3 \\
\text { Total }\end{array}$ & $\begin{array}{r}65 \\
64 \\
78 \\
64 \\
271\end{array}$ & $\begin{array}{l}18 \\
27 \\
10 \\
28 \\
83\end{array}$ & $\begin{array}{r}83 \\
91 \\
88 \\
92 \\
354\end{array}$ & & $\begin{array}{r}.50-.60 \\
.30-.40 \\
<.005 \\
.25-.30 \\
.50-.60\end{array}$ & $\begin{array}{l}.60-.70 \\
.01-.025 \\
.10-.15 \\
.005-.01 \\
.025-.05\end{array}$ \\
\hline
\end{tabular}

I/ Pot number of parental $F_{1}$ plant. 
small $\mathrm{F}_{0}$ seed. The susceptible plant from the Ward $\mathrm{x}$ Omugi population may have been a self but this could not be true for the 2 plants in the reciprocal cross. The 224 testcross hybrids segregated 121 resistant to 103 susceptible which fits a l:I ratio with a probability value between .25 and .30. A total of $354 \mathrm{~F}_{2}$ progenies of $4 \mathrm{~F}_{1}$ plants were tested. Two of the 4 populations deviated from a $3: 1$ ratio in the direction of too many susceptible plants and 2 deviated in the opposite direction. Probability values on total $\mathrm{F}_{2}$ plants were $.50-.60$ for a $3: 1$ ratio and $.025-.05$ for a $13: 3$.

\section{Dobaku $\times$ Tenkow}

Greenbug reaction data for the parents and hybrids are presented in table 4. The 1 susceptible plant among the $23 \mathrm{~F}_{1}$ plants tested may have resulted from a selfed seed or a weak plant. A good fit for a l:l ratio was obtained in the testcrosses with 70 resistant and 73 susceptible hybrids. A total of $400 \mathrm{~F}_{2}$ plants were tested and the chi-square probability value for a $3: 1$ ratio is .30-.40 compared to less than .005 for a 13:3. In 2 of the 4 populations the deviations from the expected $3: 1$ ratio were in the direction of too many susceptible plants. However, in the total this was counteracted in part by the too few susceptible plants in the population 60 G $980-2$.

\section{Dobaku $\times$ Ward}

Four of the $37 \mathrm{~F}_{1}$ plants tested from crosses of these varieties were classified susceptible (table 5). These could not be selfs since Dobaku was the female parent but perhaps they could have been weak seedlings. It should be mentioned that 3 Dobaku plants were also susceptible. The testcrosses segregated 56 resistant to 43 susceptible. Although the tendency is toward too many resistant plants this fits a $1: 1$ ratio with 
Table 4.--Greenbug reaction of parents and $F_{1}$, testcross and $F_{2}$ hybrids of Dobaku and Tenkow.

\begin{tabular}{|c|c|c|c|c|c|c|}
\hline \multirow[t]{2}{*}{ Variety or cross } & \multicolumn{3}{|c|}{ Number of plants } & \multicolumn{3}{|c|}{$P$ values for res. asusc, ratios of: } \\
\hline & Res. & Susc. & Total & $1: 1$ & $3: 1$ & $13: 3$ \\
\hline $\begin{array}{l}\text { Parents } \\
\text { Dobaku } \\
\text { Tenkow }\end{array}$ & $\begin{array}{r}124 \\
0\end{array}$ & $\begin{array}{r}1 \\
172\end{array}$ & $\begin{array}{l}125 \\
172\end{array}$ & & & \\
\hline $\begin{array}{l}\text { F }_{1} \text { hybrids } \\
\text { Dobaku x Tenkow } \\
\text { Tenkow x Dobaku } \\
\text { Total }\end{array}$ & $\begin{array}{r}15 \\
7 \\
22\end{array}$ & $\begin{array}{l}0 \\
1 \\
1\end{array}$ & $\begin{array}{r}15 \\
8 \\
23\end{array}$ & & & \\
\hline $\begin{array}{l}\text { Testcross hybrids } \\
\text { Tenkow } \mathrm{x} \text { (Dobaku } \mathrm{x} \text { Tenkow) } \\
\text { Tenkow } \mathrm{x} \text { (Tenkow } \mathrm{x} \text { Dobaku) } \\
\text { (Dobaku } \mathrm{x} \text { Tenkow) x Tenkow } \\
\text { Total }\end{array}$ & $\begin{array}{l}23 \\
26 \\
\frac{21}{70}\end{array}$ & $\begin{array}{l}31 \\
27 \\
15 \\
73\end{array}$ & $\begin{array}{r}54 \\
53 \\
36 \\
143\end{array}$ & $\begin{array}{l}.30-.40 \\
.90-.99 \\
.40-.50 \\
.75-.90\end{array}$ & & \\
\hline $\begin{array}{l}\text { F }_{2} \text { hybrids } \\
\text { Dobaku x Tenkow } \\
60 \text { G } 959-1 \text { / } \\
60 \text { G } 959-5 \\
\text { Tenkow x Dobaku } \\
60 \text { G } 980-1 \\
60 \text { G } 980-2 \\
\text { Total }\end{array}$ & $\begin{array}{r}65 \\
72 \\
79 \\
74 \\
290\end{array}$ & $\begin{array}{r}36 \\
30 \\
26 \\
18 \\
110\end{array}$ & $\begin{array}{r}101 \\
102 \\
105 \\
92 \\
400\end{array}$ & & $\begin{array}{l}.01-.025 \\
.30-.40 \\
.90-.99 \\
.25-.30 \\
.30-.40\end{array}$ & $\begin{array}{l}<.005 \\
.005-.01 \\
.15-.20 \\
.90-.99 \\
<.005\end{array}$ \\
\hline
\end{tabular}

I Pot number of parental $F_{1}$ plant. 
Table 5.--Greenbug reaction of parents and $F_{1}$, testcross and $F_{2}$ hybrids of Dobaku and Ward.

\begin{tabular}{|c|c|c|c|c|c|c|}
\hline \multirow[t]{2}{*}{ Variety or cross } & \multicolumn{3}{|c|}{ Number of plants } & \multicolumn{3}{|c|}{$P$ values for res.:susc, ratios of: } \\
\hline & Res. & Susc. & Total & $1: 1$ & $3: 1$ & $13: 3$ \\
\hline $\begin{array}{l}\text { Parents } \\
\text { Dobaku } \\
\text { Ward }\end{array}$ & $\begin{array}{r}133 \\
0\end{array}$ & $\begin{array}{r}3 \\
155\end{array}$ & $\begin{array}{l}136 \\
155\end{array}$ & & & \\
\hline $\begin{array}{l}F_{1} \text { hybrids } \\
\text { Dobaku x Ward } \\
\text { Ward x Dobaku } \\
\text { Total }\end{array}$ & $\begin{array}{r}5 \\
28 \\
33\end{array}$ & $\begin{array}{l}4 \\
0 \\
4\end{array}$ & $\begin{array}{r}9 \\
28 \\
37\end{array}$ & & & \\
\hline $\begin{array}{l}\text { Testcross hybrids } \\
\text { Ward } \mathrm{x} \text { (Dobaku x Ward) } \\
\text { (Dobaku x Ward) } \mathrm{x} \text { Ward } \\
\text { (Ward x Dobaku) } \mathrm{x} \text { Ward } \\
\text { Total }\end{array}$ & $\begin{array}{l}17 \\
19 \\
20 \\
56\end{array}$ & $\begin{array}{r}9 \\
13 \\
21 \\
43\end{array}$ & $\begin{array}{l}26 \\
32 \\
41 \\
99\end{array}$ & $\begin{array}{l}.15-.20 \\
.40-.50 \\
.90-.99 \\
.20-.25\end{array}$ & & \\
\hline $\begin{array}{l}\mathrm{F}_{2} \text { hybrids } \\
\text { Dobaku x Ward } \\
60 \text { G } 962-1 \\
60 \text { G } 962-2 \\
\text { Ward x Dobaku } \\
60 \text { G } 992-1 \\
60 \text { G 992-2 } \\
\text { Total }\end{array}$ & $\begin{array}{r}71 \\
82 \\
83 \\
82 \\
318\end{array}$ & $\begin{array}{l}22 \\
11 \\
13 \\
14 \\
60\end{array}$ & $\begin{array}{r}93 \\
93 \\
96 \\
96 \\
378\end{array}$ & & $\begin{array}{r}.75-.90 \\
<.005 \\
.01-.025 \\
.025-.05 \\
<.005\end{array}$ & $\begin{array}{l}.25-.30 \\
.10-.15 \\
.20-.25 \\
.30-.40 \\
.15-.20\end{array}$ \\
\hline
\end{tabular}

1 Pot number of parental $F_{1}$ plant. 
a probability value between .20 and .25 . Greenbug reactions were obtained on $378 \mathrm{~F}_{2}$ hybrids of which 318 were resistant and 60 were susceptible. The probability of a $3: 1$ ratio is less than .005 as compared to .15 to .20 for a $13: 3$ ratio. In only 1 of the $4 F_{2}$ populations was a 3:1 ratio obtained, while all 4 populations are within acceptable limits for a $13: 3$ ratio. 


\section{DISCUSSION AND CONCLUSIONS}

\section{Testing Conditions}

There was some concern that the rapid growth would increase the probability of escape of susceptible segregates and cause erroneous results. Several workers $(5,23,30)$ have noted that older and more vigorous plants are more tolerant to greenbugs for short periods of time. It also seemed possible that those plants which were delayed in germination may have been weakened and would be more susceptible, even to the extent that some normally resistant seedlings would die. However, if either or both of these occurred, it should have been apparent by the response of the parents in each of the flats.

\section{Resistant $\mathrm{x}$ Resistant Variety Studies}

The results of this test indicate that Omugi, Dobaku, Kearney and C.I. 5087 have at least 1 common dominant factor controlling greenbug resistance. No major differences were apparent in the degree of resistance among the parents, $F_{1}$ 's or $F_{2}^{\prime} s$ and the design of this experiment was not adequate to ascertain the presence of secondary factors.

That Omugi and Dobaku each have a dominant factor controlling resistance is in agreement with McDonald (22), although he was unable to determine if the dominant factor was located at the same locus in both varieties. These results differ with those of McDonald in the reaction of $\mathrm{F}_{2}$ hybrids of Dobaku and C.I. 5087 from which he concluded C.I. 5087 
has a single recessive gene controlling resistance. A possible explanation for this disagreement in results involves the techniques used in the 2 studies. In his test, cages were used to confine the greenbugs to the plants. Tolerance ratings of $F_{2}$ hybrids were based on leaf injury and amount of growth, as measured by plant height, in comparison with that of the parents and an Omugi check. No susceptible check was used for comparison. Omugi and Dobaku seedlings normally grow quite vigorously as compared to C.I. 5087. As mentioned earlier, several workers have noted that even susceptible plants with more vigorous growth are more tolerant for short periods of time. Consequently, even though the 3 varieties have a common dominant resistant gene, it seems possible that in testing 2 resistant varieties by his techniques without a susceptible check, a variety with slower growth may be classified susceptible. Further evidence that C.I. 5087 has a dominant gene was obtained from an additional test in which $\mathrm{F}_{1}$ plants of Tenkow $\mathrm{x}$ C.I. 5087 were found to be resistant.

\section{Resistant $\mathrm{x}$ Susceptible Variety Studies}

\section{Genetic studies with Tenkow as the common parent.}

A $1: 1$ testcross ratio and a $3: 1 \mathrm{~F}_{2}$ ratio were obtained from hybrids of Tenkow crossed with Omugi and Dobaku. These ratios indicate 1 major factor controls the greenbug resistance of both varieties. In crosses with both varieties, 1 of the $4 F_{2}$ populations did not fit the hypothesized ratio. Moreover, the 2 populations with poor fits for a $3: 1$ ratio had even higher chi-square values for the 13:3. McDonald (22) did not test the reactions of hybrids of Dobaku and Tenkow but obtained a 9:7 ratio (indicative of duplicate dominant factors) in $\mathrm{F}_{2}$ hybrids of omugi 
and Tenkow. The $\mathrm{F}_{2}$ data from this test does not fit a 9:7 ratio and the 1:1 testcross ratio precludes the possibility of duplicate dominant genes unless the susceptible variety contained 1 of the dominant genes. That the resistance of Omugi is controlled by 1 major dominant factor is in agreement with the results of Gardenhire and Chada (17). Genetic studies with Ward as the common parent.

These results also indicate that a dominant factor controls the greenbug resistance in both Omugi and Dobaku. However, in $\mathrm{F}_{2}$ hybrids of these varieties and Ward, it appears that Dobaku may also have a recessive gene conditioning resistance which is independent of the dominant factor and which Omugi does not have. Thus a 13:3 ratio was obtained in $\mathrm{F}_{2}$ hybrids of Dobaku and Ward as compared to a $3: 1$ ratio in hybrids of Omugi and Ward. Probability values for the 13:3 ratio in each of the $\mathrm{F}_{2}$ populations of Dobaku and Ward ranged between .10 and .40 with a probability value between .15 and .20 for the total pooled chisquare. However, in one of the 4 populations tested a $3: 1$ ratio was obtained with a probability value between .75 and .90 . It is assumed that this is a result of sampling variation. A l:l testcross ratio would be expected if resistance is controlled by either 1 dominant gene or 1 dominant gene and 1 recessive gene.

McDonald (22) also obtained a $3: 1$ ratio with hybrids of Omugi and Ward and a 13:3 ratio for Dobaku and Ward. Furthermore, in his studies where Dobaku was used as a parent and Omugi as a check, Dobaku was consistently given a higher tolerance rating based on leaf injury and amount of growth. Whether this indicates an additive effect of the dominant and recessive genes, a difference in the vigor of the seedlings, or sampling variation is not known. It is interesting to note that the results 
obtained by Grant (18) and Dahms et al. (10) show the same trend in relation to the relative tolerance of Omugi and Dobaku.

No difference was noted in this test in the degree of resistance among the Dobaku $\mathrm{x}$ Ward hybrids which would indicate a lesser or greater resistance of plants having either a single recessive gene or both a dominant gene and a recessive gene. It is believed that carefully controlled tests with caged infestations would be necessary to distinguish this difference if it exists. Comparisons of the susceptible parents and their progeny.

The difference in the ratios obtained from progenies of Dobaku crossed with Ward and Tenkow appears to be indicative of a genetic difference between the 2 susceptible varieties. Another suggestion of this difference is that the deviations from the expected in the total $\mathrm{F}_{2}$ hybrids of Omugi and Tenkow were in the direction of too many susceptible plants. In the testcross and $\mathrm{F}_{2}$ hybrids of Omugi and Ward the tendency was in the opposite direction. However, it is not known if the differences with Omugi are significant. McDonald's (22) data indicate a difference in Tenkow and Ward in the ratios obtained from $\mathrm{F}_{2}$ progenies of crosses of these varieties and Omugi. The difference he found was sufficient to suggest a 9:7 ratio with Tenkow hybrids and a $3: 1$ with Ward hybrids.

Attempts were made in analyzing the data to detect differences in the response of Ward and Tenkow other than in the ratios obtained. Line graphs comparing the number of Tenkow and Ward parent plants dying each day of the test were made but no material differences were observed. There was less than 1 day's difference in the average date of death of the Tenkow and Ward parents. No important differences were found in 
comparisons of the average date of death of the susceptible $\mathrm{F}_{2}$ hybrids for each of the 4 crosses among Tenkow, Ward, Omugi and Dobaku. However, there were 18 Ward hybrids lingering at the close of the test as compared with 6 Tenkow hybrids. It appears that the only detectable difference between the susceptible varieties in this test was in the ratios obtained from the reaction of the hybrid plants. The number of hypothetical differences between Tenkow and Ward which would produce different $\mathrm{F}_{2}$ ratios when crossed with Dobaku is somewhat restricted by the $1: 1$ testcross ratio. Nevertheless, it seems possible when working with a character like greenbug tolerance that a number of factors could affect the results, particularly if multiple genes and multiple effects are involved.

One relatively simple possibility for the different ratios obtained with the Dobaku hybrids postulates the presence of a dominant nonallelic gene in Tenkow which inhibits expression of the recessive resistant gene. Ward and Dobaku would then be expected to have the recessive gene at this locus. Under these conditions $F_{2}$ hybrids of Dobaku $x$ Tenkow would be expected to segregate 49 resistant:15 susceptible, Dobaku $x$ Ward 13:3, Omugi $x$ Tenkow and Omugi $x$ Ward 3:1. All expected testcross ratios would still be 1:1. In this explanation it is assumed that the differences in crosses with Omugi are not significant. 
SUMMARY

Inheritance studies on the greenbug resistance of 4 varieties of winter barley were conducted during the period 1958-1961. The tests were to determine if the greenbug resistance of Omugi, Dobaku, Kearney and C.I. 5087 is controlled by the same or different genes and to determine the genetics of the resistance in Omugi and Dobaku.

$\mathrm{F}_{1}$ and $\mathrm{F}_{2}$ hybrids from crosses in all combinations, including reciprocals, of the resistant varieties were tested with parents and checks for their reactions to greenbugs. It appears from the results of this test that these varieties contain a common gene for resistance. No measureable differences in the degree of resistance were observed among the hybrids and parents.

$F_{1}, F_{2}$ and testcross hybrids of Omugi and Dobaku crossed with Tenkow and Ward were also tested for their reaction to greenbugs. The results indicate that both Omugi and Dobaku contain a dominant gene for resistance. Reaction data on hybrids of Dobaku and Ward provide some evidence that Dobaku may contain an additional independent recessive gene for resistance; however, in crosses with Tenkow the recessive gene was not expressed. The difference in the ratios obtained when using Tenkow and Ward as the susceptible parents suggests the possibility of modifying factors in Tenkow which prevents expression of the recessive gene. 


\section{LITERATURE CITED}

1. Atkins, I. M. and R. G. Dahms. Reaction of small-grain varieties to greenbug attack. USDA Tech. Bul. 901. 1945.

2. Bilsing, S. W. The greenbug or spring grain aphis. Tex. Agr. Exp. Sta. Circ. 13. 1916.

3. Chada, H. L., I. M. Atkins, J. H. Gardenhire and D. E. Weibel. Greenbug resistance studies with small grains. Tex. Agr. Exp. Sta. Bul. (In press).

4. Chatters, R. M. and A. M. Schlehuber. Mechanics of feeding of the greenbug (Toxopters graminum Rond.) on Hordeum, Avens, and Triticum. Okla. Agr. Exp. Sta. Tech. Bul. T-40. 1951.

5. Curtis, B. C. Genetics of greenbug (Toxopterg graminum Rond.) resistance in two strains of common wheat. Unpub. Doctor's Thesis. Okla. State Univ. 1959.

6. A. M. Schlehuber and E. A. Wood, Jr. Genetics of greenbug (Toxoptera graminum Rond.) resistance in two strains of common wheat. Agron. Jour. 52: 599-602. 1960.

7. Dahms, R. G. Comparative tolerance of small grains to greenbugs from Oklahoma and Mississippi. Jour. Econ. Ent. 41: 825-826. 1948.

8. - Preventing greenbug outbreaks. USDA Leaflet 309. 1951.

9. - R. V. Connin and W. D. Guthrie. Grasses as hosts of the greenbug. Jour. Econ. Ent. 47: 1151-1152. 1954.

10. , T. H. Johnston, A. M. Schlehuber and E. A. Wood, Jr. Reaction of small-grain varieties and hybrids to greenbug attack. Okla. Agr. Exp. Sta. Tech. Bul. T-55. 1955.

11. Daniels, N. E. Greenbug eggs below the thirty-fifth parallel. Jour. Econ. Ent. 49: 567. 1956.

12. - Evidence of the oversummering of the greenbug in the Texas Panhandle. Jour. Econ. Ent. 53: 454-455. 1960.

13. H. L. Chada, D. Ashdown and E. A. Cleveland. Greenbugs and some other pests of small grains. Tex. Agr. Exp. Sta. Bul. 845. 1956. 
14. Daniels, N. E. and K. B. Porter. Greenbug resistance studies in winter wheat. Jour. Econ. Ent. 51: 702-704. 1958.

15. Fenton, F. A. Field crop insects. MacMillan Co., New York. 1952.

16. and E. H. Fisher. The 1939 green bug outbreak in Oklahoma. Jour. Econ. Ent. 33: 628-634. 1940.

17. Gardenhire, J. H. and H. L. Chada. The inheritance of greenbug resistance in barley. Crop Sci. (In press).

18. Grant, U. J. The reaction of certain barley varieties to greenbug attack. Unpub. Master's Thesis. Okla. State Univ. 1948.

19. Hunter, S. J. The greenbug and its enemies. Kans. Univ. Bul. 9. 1909.

20. Kelly, E. O. G. The greenbug (Toxopterg graminum Rond.) outbreak of 1916. Jour. Econ. Ent. 10: 233-248. 1917.

21. Maxwell, F. G. and R. H. Painter. Factors affecting rate of honeydew deposition by Therioaphis maculata (Buck) and Toxoptera graminum (Rond.). Jour. Econ. Ent. 52: 368-373. 1959.

22. McDonald, W. H., Jr. Inheritance of resistance to the greenbug (Toxoptera graminum Rond.) in winter barley hybrids. Unpub. Master's Thesis. Okla. State Univ. 1952.

23. Painter, R. H. Insect resistance in crop plants. MacMillan Co., New York. 1951.

24. Entomological problems in developing new wheats. Cereal Science Today 5: 98-99. 1960.

25. , H. R. Bryson and D. A. Wilbur. Insects and mites that attack wheat in Kansas. Kans. Agr. Exp. Sta. Bul. 367. 1954.

26. and D. C. Peters. Screening wheat varieties and hybrids for resistance to the greenbug. Jour. Econ. Ent. 49: 546-548. 1956.

27. Patch, E. M. Food plant catalogue of the aphids of the world including the Phylloreridae. Maine Agr. Exp. Sta. Bul. 393: 35-431. 1938.

28. Ruggles, A. G. and F. M. Wadley. The greenbug in Minnesota. Jour. Econ. Ent. 20: 321-327. 1927.

29. Wadley, F. M. Ecology of Toxoptera graminum, especially to factors affecting importance in the northern United States. Ent. Soc. Amer. Ann. 24: 325-395. 1931. 
30. Walton, R。 R. Greenbug injuries on barley varieties at Woodward, Oklahoma in 1943. Okla. Acad. Sci. Proc. 24: 38-42. 1944.

31. Walton, W. R. The greenbug or spring grain aphis: How to prevent its periodical outbreaks. USDA Farmers Bul. 1217. 1921.

32. Washburn, F. L. The so-called "greenbug" and other aphids in Minnesota in 1907. Minn. Agr. Exp. Sta. Bul. 108. 1908.

33. Webster, F. M. and W. J. Phillips. The spring grain-aphis or "greenbug". USDA Bureau of Ent. Bul. 110. 1912.

34. Wiebe, G. A. and D. A. Reid. Classification of barley varieties grown in the United States and Canada in 1958. USDA Tech. Bul. 1224. 1961.

35. Wood, E. A., Jr. A Hymenopterous parasite new to Oklahoma. Jour. Econ。 Ent. 51: 553. 1958.

36. A new strain of greenbug and its effect on resistant lines of wheat. USDA-Agr. Res. Serv. Ent. Res. Div. Cereal Insects Section. Special Report W-114. (Processed) 1959. 
VITA

Olin Dail Smith

Candidate for the degree of

Master of Science

Thesis: INHERITANCE STUDIES OF GREENBUG (TOXOPTERA GRAMINUM ROND.) RESISTANCE IN FOUR VARIETIES OF WINTER BARLEY

Major Field: Agronomy (Field Crops)

Biographical:

Personal data: Born December 15, 1931 near Tonkawa, Oklahoma, the son of Kenneth Cleo and Vera Catharine Smith.

Education: Graduated from Tonkawa H1gh School, Tonkawa, Oklahoma, In May, 1949; recelved the Associate in Arts degree from Northern Oklahoma Junior College in May, 1951; recelved the Bachelor of Science degree from Oklahoma Agricultural and Mechanical College, with a major in Field Crops, in May, 1954; completed the requirements for the Master of Science degree at Oklahoma State University in May, 1961.

Experience: Born and reared on a farm; Farmer, 1954-1957; Parttime Instructor in Agriculture at Northern Oklahoma Junior College, 1955-1956; Superintendent of Wheatland Conservation Experiment Station, Cherokee, Oklahoma, 1957-1958; Instructor in Agronomy at Oklahoma State University, 1958-196l.

Member: Alpha Zeta, American Society of Agronomy, Crops Science Society of America.

Date of Final Examination: May, 1961. 